\title{
Transient appearance of fibrinolytic activity at the epithelium of the rat uterus
}

\author{
KONSTANTINOS TYMPANIDIS AND TAGE ASTRUP \\ From The James F. Mitchell Foundation, Institute for Medical Research, \\ Washington, DC, USA
}

SYNOPSIS The observation by Todd (1964) of a diffuse fibrinolytic activity related to the humap endometrium in its secretory stage initiated a reinvestigation of the development of fibrinolyti: activity in the uterus and vagina of the rat using the histochemical fibrin slide technique. In addition to the plasminogen activator known to be related to uterine vessels, in the rat in particular to myoo metrial arteries, diffuse fibrinolytic activity appeared fleetingly at the endometrial surface epithelium in relation to the oestrous cycle. Endometrial glandular epithelium remaineo inactive. The fibrinolytic activity of the endometrial epithelium is presumably released during cellular degeneration in the secretory phase. The vaginal epithelium produced fibrinolytic activit at an earlier phase of the ovarian cycle than did the endometrial epithelium.

Todd (1959), using his histochemical fibrin slide technique, localized fibrinolytic activity in the endothelium of systemic veins and venules. Studying the human endometrium in the proliferative phase, he observed a focal fibrinolytic activity related to blood vessels in the basal layer. This was followed later in the menstrual cycle by the appearance of a diffuse fibrinolytic activity in the superficial layers of the endometrium (Todd, 1964a, b). Todd suggested that this diffuse activity could be related to an exudative process, and he reported the additional, supporting finding of diffuse areas of fibrinolytic activity related to the squamous epithelium of an inflamed uterine cervix. He assumed that plasminogen activator released from the injured tissue could have been trapped in the interstitial space of the epithelium. Luginbuhl and Picoff (1966) have confirmed the observation of a diffuse fibrinolytic activity related to the human endometrium.

Recently, we observed that certain epithelial cells are able to release plasminogen activator, presumably during a process of degeneration. This applies to rat corneal epithelial cells (Pandolfi and Astrup, 1967) and to vaginal epithelial cells of the rat (Astrup, Henrichsen, Tympanidis, and King, 1967; Henrichsen and Astrup, 1967) and man (Astrup et al, 1967; Tympanidis, King, and Astrup, 1968). It was thought that these findings might shed new light on the diffuse activity described by Todd.

Received for publication 16 May 1968.
MATERIALS AND METHODS

Adult female albino rats (200 to $220 \mathrm{~g}$ ) of the Sprague Dawley strain were divided into groups of 10 as followsô group I, dioestrus; group II, prooestrus; group II oestrus; group IV, metoestrus. The stages were deter mined by examination of the vaginal smear and from the morphological and histological appearance of uterus and vagina. The animals were killed with ether. After dissecting, each uterus was weighed and, together wit the vagina, placed at $-20^{\circ} \mathrm{C}$. Localization of fibrinolytic activity was determined by the histochemical fibrin slide technique of Todd (1959) as modified (Kwaan and Astrup, 1967). Frozen sections, cut at 6 to $8 \mu$, were covered with bovine plasminogen-rich fibrinogen an\& thrombin and left for 20 minutes in a moist chamber a 10 to $15^{\circ} \mathrm{C}$ for clot stabilization before incubation fos 15 to 25 minutes at $37^{\circ} \mathrm{C}$. Vaginal smears, prepared with a cotton bud moistened in saline, were left in the re frigerator to dry on the slides. Tests for protease activit were performed with plasminogen-free bovine fibrinogenf Fibrinolytically active sites produce clear zones of lysis in the stained fibrin.

\section{RESULTS}

Fibrinolytic activity was observed, particularle around small arteries in the parametrium, myo metrium, and endometrium (Fig. 1). Veins were usually inactive (Fig. 2). In addition, lytic areas occurred at the endometrial surface epitheliurit (Fig. 1), while the glandular epithelium always remained inactive (Fig. 3). In most sections the surface epithelium became fibrinolytic during oestrus 


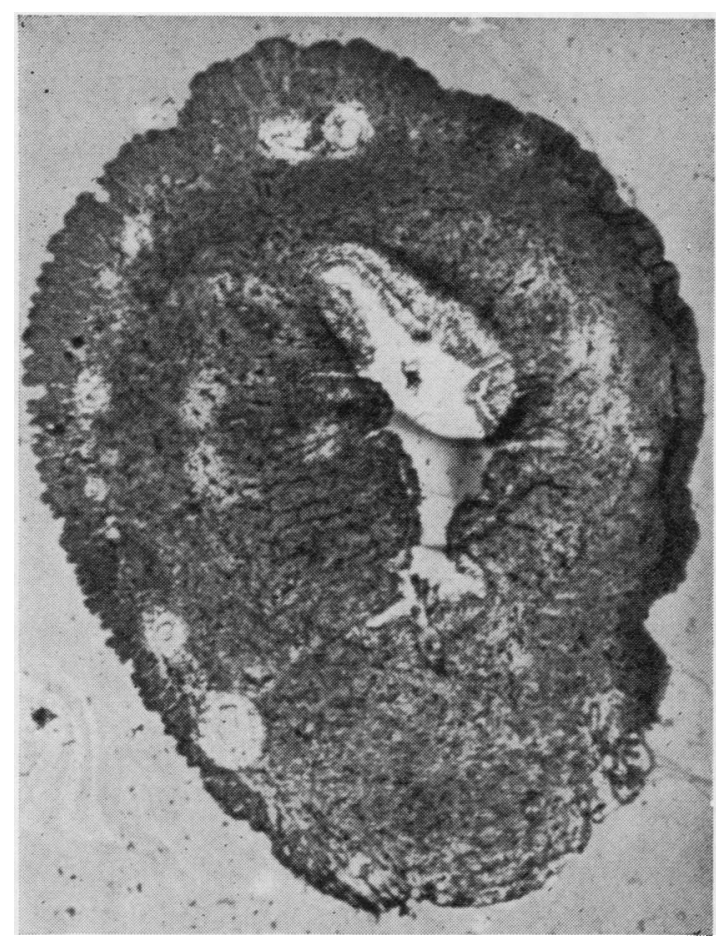

FIG. 1 .

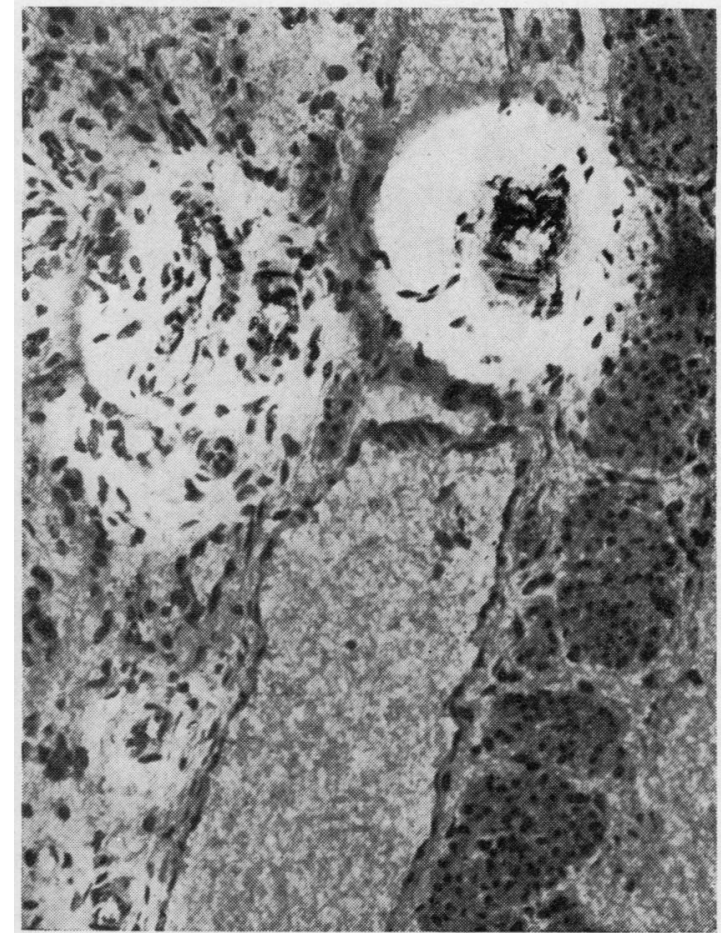

FIG. 2 .

FIG. 1. Cross section of rat uterus obtained late during the oestrus phase. Fibrinolytic activity appears as clear zones of lysis localized to myometrial and endometrial vessels and to an area of the uterine surface epithelium becoming detached. Incubated for 15 minutes. $\times 36$.

FIG. 2. Cross section of rat myometrium at prooestrus. Fibrinolytic activity localized to small arteries. Large inactive vein. Incubated for 20 minutes. $\times 175$.

(Fig. 1) though fibrinolytically active sites were unevenly distributed along the epithelial lining (Figs. 1 and 3). Fibrinolysis seemed to occur in association with cellular degeneration or desquamation (Figs. 1 and 3). At dioestrus, prooestrus, and metoestrus the fibrinolytic activity was usually localized only to the vessels (Fig. 4). In the vaginal mucosa diffuse activity appeared early in prooestrus at areas with marked desquamation. Vaginal smears collected at prooestrus contained predominantly intermediate, squamous cells, many of which were fibrinolytically active. During oestrus, the vaginal mucosa became inactive and its epithelial lining released numerous large, superficial, usually fibrinolytically inactive, squamous cells as described by Henrichsen and Astrup (1967).

Large individual variations were observed and the cellular changes in the endometrial surface epithelium or the vaginal mucosa occurred not as strictly separate phenomena, but as a continuously over- lapping, cyclic process. Sometimes, in one and the same organ, areas exhibiting different stages of the oestrus cycle could be identified. At any stage it was possible to find nucleated, as well as cornified, vaginal cells with and without fibrinolytic activity. However, high fibrinolytic activity seemed to be related to cells undergoing early degeneration.

Weak protease activity could be located in some specimens of uterus and vagina, as well as in some smears, but required two hours of incubation on plasminogen-free bovine fibrinogen.

\section{DISCUSSION}

During the oestrus cycle, the uterus and vagina undergo morphological and biochemical changes as a result of cyclic, hormonal actions. The presence of plasminogen activator is influenced by these changes (Albrechtsen, 1956, 1957; Kwaan and Albrechtsen, 1966; Henrichsen and Astrup, 1967). 


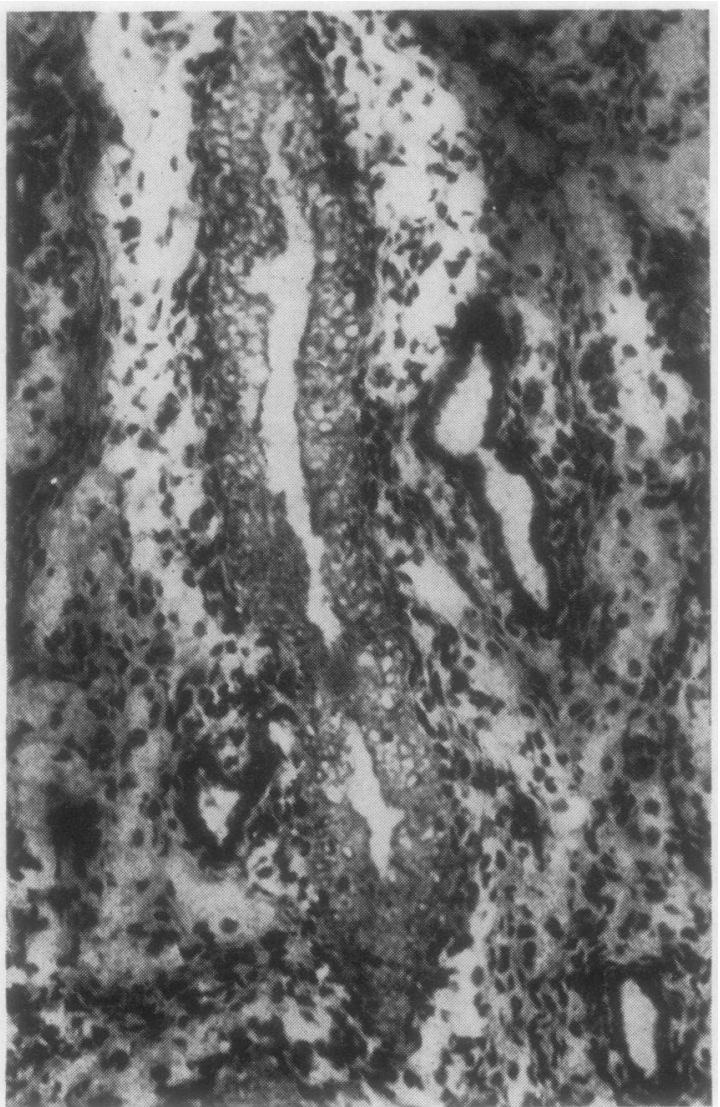

FIG. 3 .

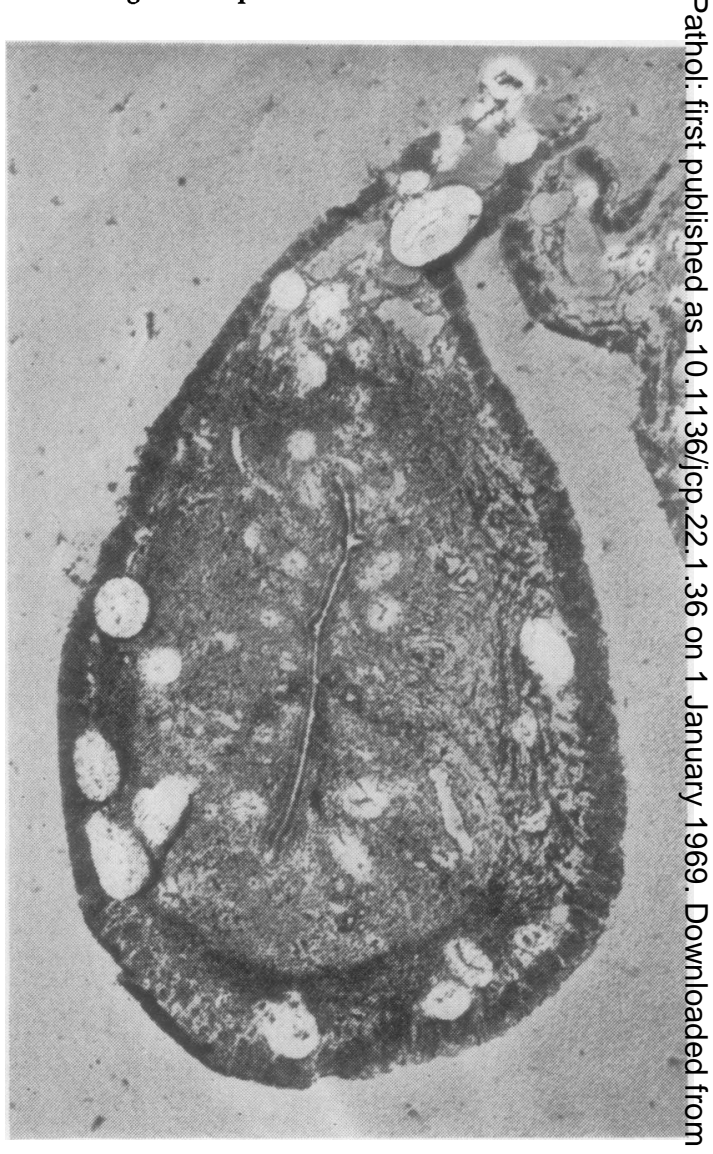

FIG. 4.

FIG. 3. Longitudinal section of rat uterus at oestrus. Fibrinolytic activity localized only to part of the endometrit surface epithelium which is undergoing degenerative vacuolization. Epithelium of endometrial glands is inactive. Incubated for 25 minutes. $\times 175$.

FIG. 4. Cross section of rat uterus at prooestrus. Fibrinolytic activity is related to parametrial, myometrial, and endometrial vessels. The endometrial surface is simple, columnar, and without activity. Incubated for 20 minutes. $\times 25$.

Studied histochemically, fibrinolytic activity was observed in relation to two different structures of the rat uterus and vagina: (1) to blood vessels, or (2) to the surface epithelium of the endometrium and the vaginal mucosa. The number of active vessels varied individually, and also from one section to another of the same specimen. Mostly the active vessels in parametrium and myometrium were small arteries. In contrast, in the human myometrium and endometrium, Todd (1959) found fibrinolytic activity related to veins. Perhaps this discrepancy could be caused by species differences.

The diffuse fibrinolytic activity observed at the endometrial surface and at the vaginal epithelium is of a transient nature. Its appearance in the vagingत्रु epithelium at an earlier stage of the oestrus cycte than in the endometrium could suggest that the epithelial cells of the two organs respond different/y to the same hormonal influence. The glandulä epithelium, which has a low mitotic rate during ân phases of the oestrus cycle (Bertalanffy and La" 1963), remained fibrinolytically inactive. In contraso when the hypertrophied endometrial surface epi thelium began to degenerate it became fibrinolyti产 In the vagina epithelial fibrinolytic activity appearege at the proliferative stage. The thickness of the vagin epithelium fluctuates during the ovarian cycle, anf the number of cellular layers in the stratified, 
squamous vaginal epithelium reaches its maximum during prooestrus. Frequently, fibrinolytic activity was found related to areas of desquamation. Interestingly, Kwaan and Albrechtsen (1966) had observed fibrinolytic activity around a few desquamated cells in the uterine cavity of rats treated with oestradiol. In the vaginal smears mostly younger cells, or cells undergoing degeneration, were fibrinolytically active. Our findings could suggest that the diffuse activity observed by Todd (1964a) in the human endometrium in the late secretory stage is of epithelial origin. Supporting this concept are reports of a hormonally influenced fibrinolytic activity in uterine fluids (Huggins, Vail, and Davis, 1943; Harpel, Bang, Homburger, and Treger, 1966). The appearance of uterine fluid coincides with the peak of mitotic activity of the uterine surface epithelium (Deane, 1952; Bertalanffy and Lau, 1963).

This study was supported by grant HE-05020 from the US Public Health Service, National Institutes of Health, National Heart Institute.
K. Tympanidis is the recipient of a fellowship from the Population Council, The Rockefeller University, New York.

\section{REFERENCES}

Albrechtsen, O. K. (1956). Acta endocr. (Kbh.), 23, 207.

(1957). Proc. Soc. exp. Biol. (N.Y.), 94, 700.

Astrup, T., Henrichsen, J., Tympanidis, K., and King, A. E. (1967). Nature (Lond.), 214, 297.

Bertalanffy, F. D., and Lau, C. (1963). Acta anat. (Basel), 54, 39.

Deane, H. W. (1952). Amer. J. Anat., 91, 363.

Harpel, P., Bang, N. U., Homburger, F., and Treger, A. (1966). Proc. Soc. exp. Biol. (N.Y.), 122, 1192.

Henrichsen, J., and Astrup, T. (1967). J. Path. Bact., 93, 706.

Huggins, C., Vail, V. C., and Davis, M. E. (1943). Amer. J. Obstet. Gynec., 46, 78

Kwaan, H. C., and Albrechtsen, O. K. (1966). Ibid., 95, 468.

- , and Astrup, T. (1967). Lab. Invest., 17, 140.

Luginbuhl, W. H., and Picoff, R. C. (1966). Amer. J. Obstet. Gynec. 95, 462.

Pandolf, M., and Astrup, T. (1967). Arch. Ophthal., 77, 258.

Todd, A. S. (1959). J. Path. Bact., 78, 281.

- (1964a). J. clin. Path., 17, 324.

- (1964b). Brit. med. Bull., 20, 210.

Tympanidis, K., King, A. E., and Astrup, T. (1968). Amer. J. Obstet. Gynec., 100, 185. 